\title{
中温および高温メタン発醖に及ぼす高級脂 肪酸の阻害効果の比較
}

\author{
褚春鳳 ${ }^{1} \cdot$ 李玉友 $^{2} \cdot$ 宮原高志 $^{3} \cdot$ 野池達也 $^{4}$ \\ ${ }^{1}$ 学生会員 工修 東北大学博士後期課程学生 工学部土木工学科（テ980-77 仙台市青葉区荒巻字青葉） \\ 2 正会員 工博 ア夕力工業 (株) 技術研究所 (广551大阪市大正区船町 2丁目 2-11) \\ ${ }^{3}$ 正会員 工博 東北大学講師 工学部土木工学科（９ 980-77 仙台市青葉区荒巻字青葉） \\ ${ }^{4}$ 正会員 工博 東北大学教授 工学部土木工学科（テ980-77 仙台市青葉区荒巻字青葉）
}

\begin{abstract}
中温および高温条件における酷酸資化性メタン生成に対する高級脂肪酸の阻害特性を回分実験を通して比 較検討を行った. 飽和高級脂肪酸はテカン酸 $\left[\mathrm{C}_{10: 0}\right]$, ラウリン酸 $\left[\mathrm{C}_{12: 0}\right]$, ミリスチン酸 $\left[\mathrm{C}_{14: 0}\right]$, パルミチ ン酸 $\left[\mathrm{C}_{16: 0}\right]$ およびステアリン酸 $\left[\mathrm{C}_{18: 0}\right]$ を用い,不飽和高級脂肪酸はエライジン酸 $\left[\mathrm{C}_{18: 1}(\operatorname{trans})\right]$, オレイン酸 $\left[\mathrm{C}_{18: 1}(\mathrm{cis})\right]$, リノール酸 $\left[\mathrm{C}_{18: 2}\right]$, リノレン酸 $\left[\mathrm{C}_{18: 3}\right]$ を用いた. 中温と高温のいずれの条件においても不飽和高

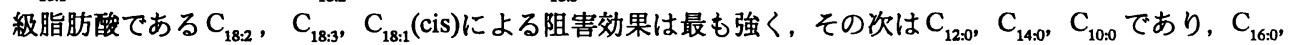
$\mathrm{C}_{18: 0}$ および $\mathrm{C}_{18: 1}$ (trans)による阻害効果は比較的小さかった. 高級脂肪酸による阻害効果は高温条件で著しく 悢和されている.
\end{abstract}

Key Words : acetate, anaerobic treatment, inhibition, long-chain fatty acid, methanogenesis, mesophilic, thermophilic

\section{1. はじめに}

嫌気性処理は好気性処理法に比べ,(1)ばっ気が不要 なのでエネルギーを節約できる, (2)余剩污泥の発生量 が少ない,(3)メタンガスを回収利用できる等の利点が ある. また, 嫌気性ろ床法およびUASB リアクター に代表される高効率プロセスの採用により，COD負 荷を $10 な い し$ 数 $10 \mathrm{~kg} / \mathrm{m}^{3} / \mathrm{d}$ まで高めることができる. この值は好気性活性污泥法の実用負荷 $\left(1 \mathrm{~kg} / \mathrm{m}^{3} / \mathrm{d}\right.$ 以 下）の数 10 倍に当たる. 従って，中・高濃度工場排 水の処理における嫌気性プロセスの採用は, 処理コ ストの低隇, 有価資源の回収および所用敷地の節約 につながる.このような利点があるため, 近年, 嫌気 性処理プロセスの応用範囲の拡大を目標之する様々 な研究が内外において活発に行われている1).

脂質は食品工場排水, 下水污泥, 食堂排水, 都市下 水, パーム油工場排水などに40 33,000 mg/Lの濃度で 含まれており, 特に下水污泥の場合は, 全 COD の $42 \%$, 食堂排水は $30 \%$, 都市下水は 20 25\%を脂質が 占めている2゙-の，脂質の加水分解によって生成する高 級脂肪酸(LFA)はその嫌気的分解過程で次のような問
題があるため， 難分解性または阻害性物質と見なさ れている.

(1) LFAの嫌気的分解は水素生成性酢酸生成細菌によ り行われ，その反応が熱力学的に不利なため, 酢 酸または水素利用細菌との共生反応は必要不可欠 である. そのため，LFA分解は， $\beta$-酸化の生成物 である水素に阻害されることもあり, 分解システ 么全体の律速段階となりがちである.

(2) LFA は, 特に（酢酸, 水素利用者である) メタン 生成細菌に対して吸着阻害性を有するため, 高濃 度のLFAはメタン発酵プロセスを失敗させる原因 物質となる7).

このように, LFA は嫌気性処理において蓄積し易 く, その結果, 污泥の沈降性を悪化させたり, 微生物 の働きに阻害作用をもたらしたりして，処理効果に 悪影響を及ぼす場合が多い。これらの問題を解決す るために，嫌気性処理におけるLFAの挙動に関する 研究が注目を集めている.

LFA は中温嫌気性細菌に対して強い阻害効果を有 することはすでに花木ら ${ }^{8)}$, Koster $ら^{9)}$, Prins $ら^{10)}$ 及 び亀井ら ${ }^{111}$ 報告されている.また, 花木ら ${ }^{8)} \mathrm{Ca}^{2+}$, 
$\mathrm{Mg}^{2+}$ の添加により, 中性 $\mathrm{pH}$ 域において水中に陰イオ ンとして存在するLFAがそれと結合して不溶性の石 けんかすを形成させることで, LFAによる阻害を緩和 することができたことを報告している. Komatsu ら ${ }^{12)}$ は不飽和LFAの阻害性は飽和LFAより強いことに着 目して, 二相消化法を採用することで, 阻害効果の強 い不飽和LFAを酸生成相で飽和LFAに変換させ, メ タン生成相におけるLFAの阻害性を軽隇できたこと を報告している. Aki ら ${ }^{13}$ は は粒子状活性炭の添加によ り, LFA の吸着性を促進し, 遊離 LFAの濃度を減少 させることで, LFAによる阻害効果を緩和できると 同時に, 粒状活性炭は共生微生物の增殖, 固定化に寄 与し, 結果としてLFAの分解反応を促進したことを 見出した. このように, 既往の研究は大きく分けて (1)嫌気性処理に及ぼすLFAの阻害効果の把握之緩和 方法の検討, (2)嫌気性処理における LFA の分解の促 進という二つの課題に集約されている. しかし, 従来 の研究は中温処理に集中しており, LFAの分解性お よび阻害性に対する温度の影響はほとんど知られて いない.

嫌気性処理は反応槽温度によって無加温嫌気性処 理, 中温嫌気性処理 $\left(35^{\circ} \mathrm{C}\right.$ 前後)および高温嫌気性処 理 $\left(50 \sim 55^{\circ} \mathrm{C}\right)$ に分けることができる.一般に，高温嫌 気性処理の反応速度は高く, 特に固体およびスラ リ一状の廃水に対しては中温処理と比較して高温処 理の効率が高いことが報告されている ${ }^{14)}$.このため, 糖蜜工場, コーヒー工場, フルフラール, くえん酸工 場, 焼酎廃液, 食品工場などのような高温（温度 $\left.60 \sim 90^{\circ} \mathrm{C}\right)$ ・高濃度 $(10 \sim 120 \mathrm{gCOD} / \mathrm{L})$ 排水 ${ }^{2), 15)-20)}$ に対し ては高温嫌気性処理が適していると考えられる.

本研究では, 中温および高温における LFA 阻害効 果を比較することを目的として, 酢酸資化性メタン 生成反応に対する飽和 LFA $\left(\mathrm{C}_{10: 0}, \mathrm{C}_{12: 0}, \mathrm{C}_{14: 0}, \mathrm{C}_{16: 0}\right.$, $\left.\mathrm{C}_{18: 0}\right)$ および不飽和 LFA ( $\mathrm{C}_{18: 1}$ (trans), $\mathrm{C}_{18: 1}$ (cis), $\mathrm{C}_{18: 2}$, $\mathrm{C}_{18: 3}$ )の阻害効果について検討を行った. また, LFA による阻害効果をそれらの化学特性及び温度条件之 関連させて考察を行った。

\section{2. 実験方法}

\section{（1）種污泥}

本研究に用いた中温および高温種污泥は, それぞ れ $\mathrm{M}$ 流域下水処理場の中温污泥消化槽および $\mathrm{T}$ 下水 処理場の高温污泥消化槽より採取した消化污泥に酢 酸を単一有機炭素源とした人工合成基質を添加して,

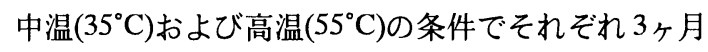
以上馴致したものである. 污泥馴致用基質の組成
Table 1 Media composition of batch culture.

\begin{tabular}{|c|c|}
\hline Nutrient & Concentration \\
\hline Sodium Acetate & $1.0-2.0 \mathrm{~g} / \mathrm{L}$ \\
\hline Resazurine & $0.002 \mathrm{~g} / \mathrm{L}$ \\
\hline Mineral solution ${ }^{(a)}$ & $10 \mathrm{ml} / \mathrm{L}$ \\
\hline Vitamin solution ${ }^{(b)}$ & $10 \mathrm{ml} / \mathrm{L}$ \\
\hline $\mathrm{KH}_{2} \mathrm{PO}_{4}$ & $0.4 \mathrm{~g} / \mathrm{L}$ \\
\hline $\mathrm{K}_{2} \mathrm{HPO}_{4}$ & $0.4 \mathrm{~g} / \mathrm{L}$ \\
\hline $\mathrm{NH}_{4} \mathrm{Cl}$ & $1.0 \mathrm{~g} / \mathrm{L}$ \\
\hline $\mathrm{MgCl}_{2} \cdot 6 \mathrm{H}_{2} \mathrm{O}$ & $0.21 \mathrm{~g} / \mathrm{L}$ \\
\hline $\mathrm{Na}_{2} \mathrm{~S} \cdot 9 \mathrm{H}_{2} \mathrm{O}$ & $0.25 \mathrm{~g} / \mathrm{L}$ \\
\hline $\mathrm{L}-\mathrm{Cysteine} \cdot \mathrm{HCl} \bullet \mathrm{H}_{2} \mathrm{O}$ & $0.5 \mathrm{~g} / \mathrm{L}$ \\
\hline $\mathrm{NaHCO}_{3}$ & $4.36 \mathrm{~g} / \mathrm{L}$ \\
\hline $\mathrm{pH}$ & $7.0-7.2$ \\
\hline
\end{tabular}

(a)Contains, in grams per liter of distilled waster:

$\mathrm{N}\left(\mathrm{CH}_{2} \mathrm{COOH}\right)_{3}, 4.5 ; \mathrm{FeCl}_{2} \bullet 4 \mathrm{H}_{2} \mathrm{O}, 0.4 ; \mathrm{CoCl}_{2}$. $6 \mathrm{H}_{2} \mathrm{O}, 0.12 ; \mathrm{AlK}(\mathrm{SO} 4)$, 0.01; $\mathrm{NaCl}, 1.0$; $\mathrm{CaCl}_{2}, 0.02 ; \mathrm{Na}_{2} \mathrm{MoO}_{4}, 0.01 ; \mathrm{MnCl}_{2} \cdot 4 \mathrm{H}_{2} \mathrm{O}$, $0.10 ; \mathrm{ZnCl}_{2}, 0.10 ; \mathrm{H}_{3} \mathrm{BO}_{3}, 0.01 ; \mathrm{CuSO}_{4} \cdot 5 \mathrm{H}_{2} \mathrm{O}$, $0.01 ; \mathrm{NiCl}_{2} \cdot 6 \mathrm{H}_{2} \mathrm{O}, 0.02$.

(b)Contains, in milligrams per liter of distilled waster: biotin, 2; folic acid, 2; pyridoxine $\mathrm{HCl}$, 10; thiamine $\mathrm{HCl}, 5$; riboflavin, 5; nicotinic acid, 5; DL-calcium pantothenate, 5; Vitamin $\mathrm{B}_{12}, 0.1 ; \mathrm{p}$-aminobenzoic acid, 5; lipoic acid (DL-thioctic acid),5.

$\left(\mathrm{mg} \cdot \mathrm{L}^{-1}\right)$ は, 酢酸: 5000; $\left(\mathrm{NH}_{4}\right)_{2} \mathrm{HPO}_{4}: 700 ; \mathrm{MgSO}_{4}$ • $7 \mathrm{H}_{2} \mathrm{O}: 250 ; \mathrm{NH}_{4} \mathrm{Cl}: 850 ; \mathrm{KCl}: 750 ; \mathrm{MgCl}_{2} \bullet 6 \mathrm{H}_{2} \mathrm{O}: 810$; $\mathrm{FeCl}_{3} \cdot 6 \mathrm{H}_{2} \mathrm{O}: 420 ; \mathrm{NaHCO}_{3}: 6720 ; \mathrm{CoCl}_{2} \cdot 6 \mathrm{H}_{2} \mathrm{O}: 18$ て あった. また, 中温および高温の種污泥は嫌気性ケモ スタット型反応槽を用いて滞留時間 10 日で培養し た.

\section{（2）試薬および培地}

全てのLFAはそのナトリウム塩試薬を用いた. 飽和 LFA はテカン酸 $\left[\mathrm{C}_{10: 0}\right]$, ラウリン酸 $\left[\mathrm{C}_{12: 0}\right]$, ミリスチ ン酸 $\left[\mathrm{C}_{14: 0}\right]$ ，パルミチン酸 $\left[\mathrm{C}_{16: 0}\right]$ およびステアリン酸 $\left[\mathrm{C}_{18: 0}\right]$ を用い, 不飽和LFAはエライジン酸 [C $\left.\mathrm{C}_{18: 1}(\operatorname{trans})\right]$, オレイン酸 $\left[\mathrm{C}_{18: 1}(\mathrm{cis})\right]$, リノール酸 $\left[\mathrm{C}_{18: 2}\right]$, リノレン 酸 $\left[\mathrm{C}_{18: 3}\right]$ を用いた. $\mathrm{C}_{16: 0}$ は東京化成工業株式会社の薬 品を用いた. それ以外の LFA は和光工業株式会社の 薬品を用いた. Table 1 は阻害実験用基礎培地を示し た. LFA 濃度はこの酢酸を単一有機炭素源とした基 礎培地に添加するLFA 量を変化させて調整した. 


\section{（3）阻害実殹の操作および分析方法}

本研究に用いた実験装置は $120 \mathrm{ml}$ のバイアル瓶を

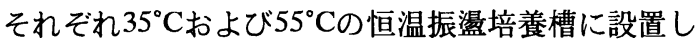
たものである.バイアル瓶には, それぞれ種污泥 $40 \mathrm{ml}$ と LFA 濃度を調整した培地 40mlを注入した．また， 阻害実験では種污泥が空気と接触することを避ける ため, バイアル瓶の気相部を $\mathrm{N}_{2}(80 \%)+\mathrm{CO}_{2}(20 \%)$ の 混合ガスで換気しながら注射器を用いて種污泥 $40 \mathrm{ml}$ を注入し，速やにプチルゴム栓とアルミ製締金属で 密栓した. 次に注射器を用いて LFA 濃度を調整した 培地 $40 \mathrm{ml}$ を注入し, 1 分間ほど換気した. また, $\mathrm{pH}$ によるメタン生成細菌への阻害の影響を無視するた め, この時点で $\mathrm{pH} 7.1$ 程度になるように調整した。

種污泥の菌体濃度は阻害実験直前に測定した。実 験期間中, ガス生成量およびガス組成を測定した. ガ ス生成量はゴム栓に注射器を差し込むことによって 定量した. ガス組成 $\left(\mathrm{N}_{2}, \mathrm{CO}_{2}, \mathrm{CH}_{4}\right)$ は $\mathrm{TCD}$ 式ガス クロマトグラフを用いて測定した. $\mathrm{pH}$ は下水試験法 に従って測定した. 本研究ではLFAが菌体に付着す ることによる影響を除くためにタンパク質濃度を菌 体量の指標とした ${ }^{21)}$. タンパク質の定量は Lowry 法 により行い,(菌体タンパク質 $) /(\mathrm{VSS})=0.6^{22}$ の換算係数 を用いて菌体 VSS 量を算出した。

\section{3. 実鏂結果}

\section{（1）異なるLFA濃度条件下でのメタン生成 活性の求め方}

中温 $35^{\circ} \mathrm{C}$ おび高温 $55^{\circ} \mathrm{C}$ の条件で，眽酸を基質と した培地に, 飽和 $\operatorname{LFA}\left(\mathrm{C}_{10: 0}, \mathrm{C}_{12: 0}, \mathrm{C}_{14: 0}, \mathrm{C}_{16: 0}, \mathrm{C}_{18: 0}\right)$ および不飽和 LFA(C $\mathrm{C}_{18: 1}$ (trans), $\mathrm{C}_{18: 1}(\mathrm{cis}), \mathrm{C}_{18: 2}, \mathrm{C}_{18: 3}$ ) をそれぞれ添加して, 一連の回分実験を行い, 酷酸資 化性メ夕ン生成反応に対する各LFAの阻害特性を検 討した. Fig. 1に一例として高温実験における累積メ タン生成量の経時変化に及ぼす $\mathrm{C}_{12: 0}$ 濃度の影響を示 した. 実験の初期において各条件での累積メタン生 成量は時間の経過とともに直線的に増加しており, その直線の傾きは各 $\mathrm{C}_{12: 0}$ 濃度条件下でのメタン生成 活性を表している。ここで求めたメタン生成活性は $\mathrm{C}_{\text {12: }}$ 濃度の増大に伴って変化している. 本研究では 各 LFA 濃度におけるメタン生成活性(ACT)を次のよ うに定義した.

$$
\mathrm{ACT}=\frac{\mathrm{V}_{\mathrm{i}}}{\mathrm{V}_{\mathrm{o}}}
$$

ここで,

$\mathrm{V}_{\mathrm{o}}$ : 阻害剤がない時の基質分解活性

$\mathrm{V}_{\mathrm{i}}$ : 阻害凨がある時の基質分解活性

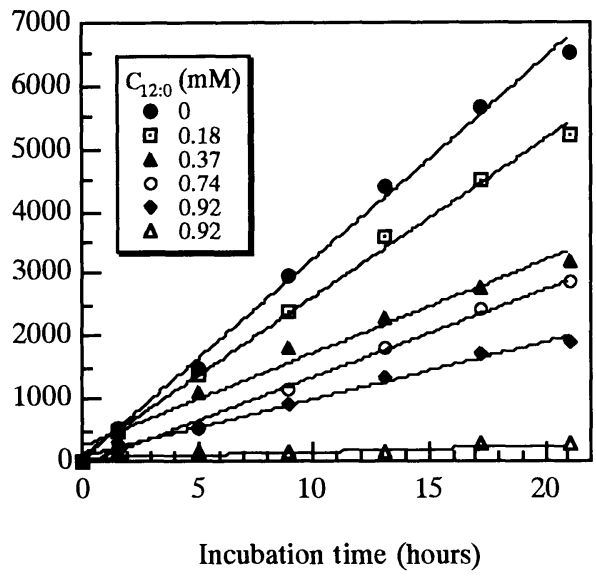

Fig. 1 Cumulative methane production at different concentration of $\mathrm{C}_{12: 0}$ in thermophilic condition.

Han and Levenspiel ら ${ }^{23}$ の研究によれば, 最大比基 質利用速度に及ぼす阻害剂添加濃度の影響は次式で 表される。

$$
\mathrm{k}^{*}=\left[1-\frac{\mathrm{C}_{\mathrm{i}}}{\mathrm{C}_{\mathrm{i}}^{*}}\right]^{\mathrm{n}}
$$

ここで

$\mathrm{k}^{*}$ : 相対最大比基質利用速度

$\mathrm{C}_{\mathrm{i}}$ : 阻害剂濃度

$\mathrm{C}_{\mathrm{i}}^{*}{ }^{*}$ : 活性がなくなる阻害剤の限界濃度

$\mathrm{n}$ : 定数

本研究で定義したACTは式(2)の $\mathrm{k}^{*}$ に相当することお よびLFAによる阻害は菌体量と関係していることか ら，ACTに対する同一阻害物の影響を式(3)で表現で きると考えて, 得られた実験デー夕を解析した結果 をFig. 2 に示す.

$$
\mathrm{ACT}=\left[1-\frac{\mathrm{L}_{\mathrm{i}}}{\mathrm{L}_{\mathrm{i}}^{*}}\right]^{\mathrm{Z}}
$$

ここで,

$\mathrm{L}_{\mathrm{i}}$ ：阻害剂負荷

$\mathrm{L}_{\mathrm{i}}^{*}$ ：活性がなくなる阻害剤の限界負荷

$\mathrm{z}$ : 定数

Fig. 2 において点は実験デー夕を示し，曲線は実験 データに基づき式(3)より解析した最終結果の回帰曲 線を示している. 

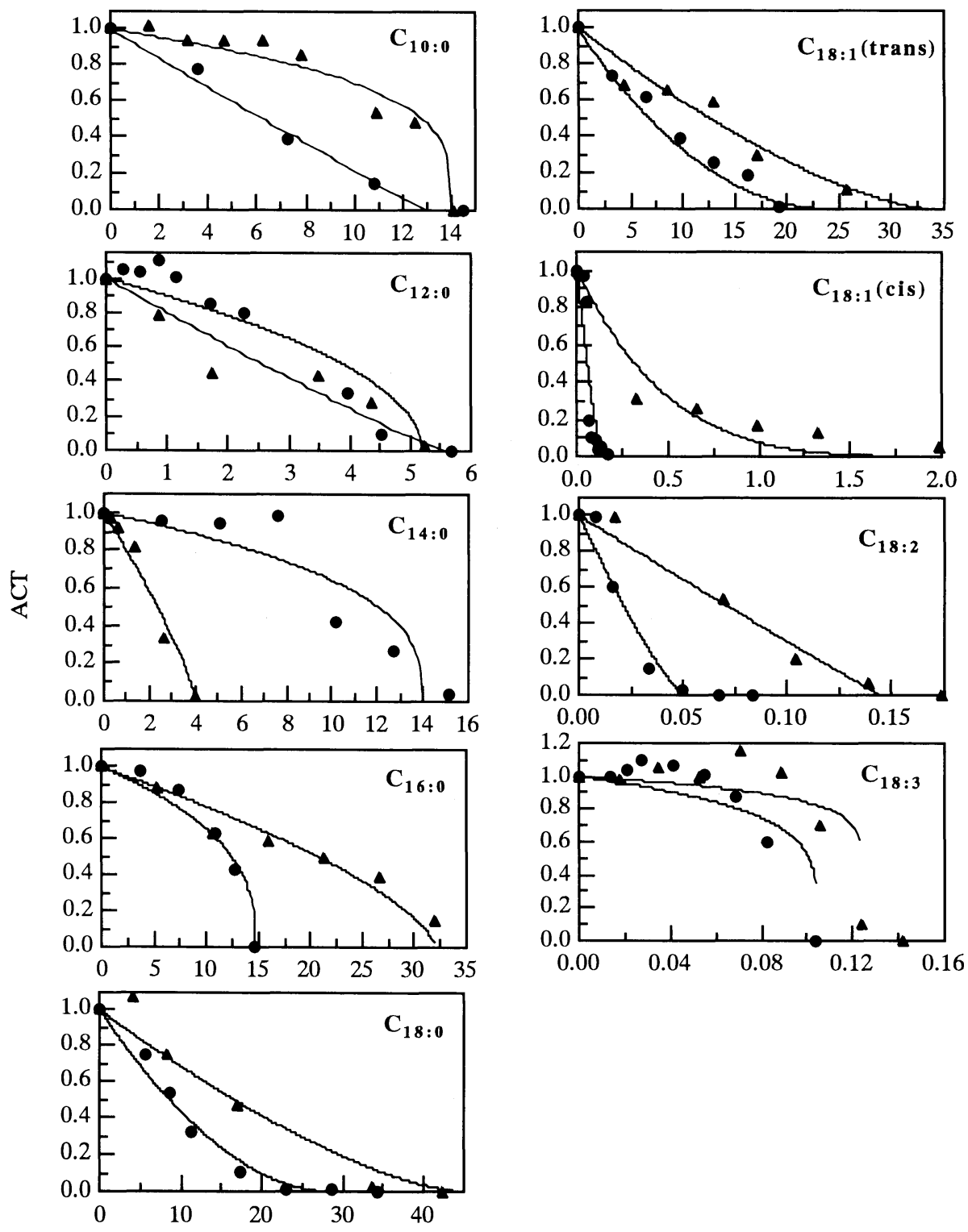

LFA (mmol/gVSS)

Fig. 2 Inhibition of relative activities by LFA. Symbols: - experimental date at $35^{\circ} \mathrm{C}$; experimental date at $55^{\circ} \mathrm{C}$. Curves in figures are theoretical predictions fitted to the date.

（2）中温および高温における相対メタン生 成活性(ACT)に対するLFAの阻害影㸷

Fig. 2は中温および高温条件下での相対メタン生成 活性 ACT に及ぼす各種 LFA 負荷の影響を示してい る. $\mathrm{C}_{14: 0}$ を除いてあらゆる実験条件においてLFAに よる阻害効果は高温の方が低いことが明らかである. これらの結果はLFAによるメタン生成活性への阻害 が高温嫌気性処理を行うことで緩和されることを示 唆している.
また, Fig. 2 は式(3)を用いて，阻害剂負荷の変化に 伴う ACTの変化傾向を表現できることも示してい る. 式(3)を用いて, 非線形回帰によって求めた中温 および高温条件下での各LFAの限界負荷 $\mathrm{L}_{\mathrm{i}}^{*}$ 之阻害指 数 $\mathrm{z}$ の值を Table 2 に示す.これらのパラメータの有 意性を検定するため, $\mathrm{t}$-テストを行った. 実測值と計 算值の相関係数 $\mathrm{R}^{2}, \mathrm{t}$ 值および信頼区間を Table 2 に まとめた. 相関係数は 0.831 以上であった. 式(3)を用 いて阻害剤負荷に対するACTの変化傾向が表現でき 
Table 2 Summary of the inhibition coefficients and statistic indicators obtained using equation (3) to analyze the experimental date show in Fig. 2.

\begin{tabular}{|c|c|c|c|c|c|c|c|c|c|c|}
\hline \multirow[b]{3}{*}{ LFA } & \multicolumn{5}{|c|}{$35^{\circ} \mathrm{C}$} & \multicolumn{5}{|c|}{$55^{\circ} \mathrm{C}$} \\
\hline & \multicolumn{2}{|c|}{ inhibition coefficients } & \multicolumn{3}{|c|}{ statistic indicators } & \multicolumn{2}{|c|}{ inhibition coefficients } & \multicolumn{3}{|c|}{ statistic indicators } \\
\hline & $\begin{array}{c}\mathrm{L}_{\mathrm{i}}^{*} \\
(\mathrm{mmol} / \mathrm{gVS}\end{array}$ & $\mathbf{Z}$ & $\mathbf{R}^{2}$ & t-value & $\begin{array}{c}\text { Confidence } \\
\text { intervals }\end{array}$ & $\begin{array}{c}\mathrm{L}_{\mathrm{i}}^{*} \\
(\mathrm{mmol} / \mathrm{gV}\end{array}$ & & $\mathrm{R}^{2}$ & t-value & $\begin{array}{l}\text { onfidence } \\
\text { intervals }\end{array}$ \\
\hline $\mathrm{C}_{10: 0}$ & 13 & 1.1 & 0.988 & 5.06 & $99 \%$ & 14 & 0.3 & 0.929 & 1.89 & $90 \%$ \\
\hline $\mathrm{C}_{12: 0}$ & 5.2 & 0.50 & 0.963 & 1.86 & $90 \%$ & 5.6 & 1.1 & 0.862 & 2.77 & $95 \%$ \\
\hline $\mathrm{C}_{14: 0}$ & 14 & 0.35 & 0.831 & 2.89 & $97 \%$ & 4.0 & 0.8 & 0.979 & 2.42 & $94 \%$ \\
\hline $\mathrm{C}_{16: 0}$ & 15 & 0.37 & 0.985 & 2.67 & $96 \%$ & 32 & 0.7 & 0.958 & 3.11 & $98 \%$ \\
\hline $\mathrm{C}_{18: 0}$ & 29 & 2.0 & 0.981 & 4.15 & $99 \%$ & 45 & 1.5 & 0.959 & 2.41 & $93 \%$ \\
\hline $\mathrm{C}_{18: 1}(\operatorname{trans})$ & 23 & 1.6 & 0.990 & 3.45 & $99 \%$ & 34 & 1.5 & 0.941 & 2.64 & $95 \%$ \\
\hline $\mathrm{C}_{18: 1}(\mathrm{cis})$ & 0.14 & 1.3 & 0.866 & 1.93 & $91 \%$ & 2.7 & 5.5 & 0.942 & 2.03 & $91 \%$ \\
\hline $\mathrm{C}_{18: 2}$ & 0.051 & 1.3 & 0.953 & 2.51 & $93 \%$ & 0.14 & 1.0 & 0.980 & 2.70 & $95 \%$ \\
\hline $\mathrm{C}_{18: 3}$ & 0.10 & 0.20 & 0.933 & 1.86 & $90 \%$ & 0.12 & 0.10 & 0.911 & 1.94 & $90 \%$ \\
\hline
\end{tabular}

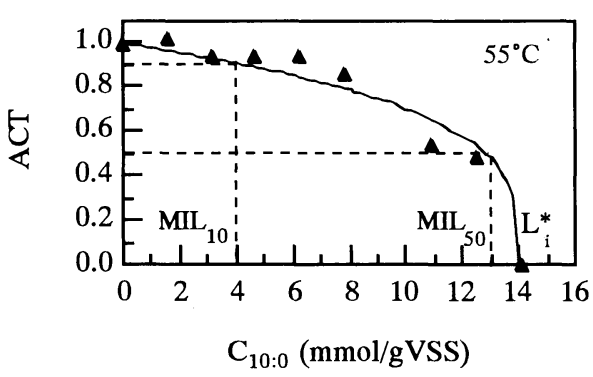

Fig. 3 Determination of MIL $_{10}$ MIL $_{50}$ by using experimental date and equation (3).
る場合, $\mathrm{L}_{\mathrm{i}}^{*}$ が小さいほど阻害性が大きく, また zが 大きいほどACT の低下はより低い濃度で起きる. Table 2 に示したように, 同一のLFAに対して高温で の $\mathrm{L}_{\mathrm{i}}^{*}$ 值は中温のそれより高く, 高温で阻害効果は若 干緩和されたことを意味している．また同じ温度条 件では飽和 LFAの $\mathrm{L}_{\mathrm{i}}^{*}$ は $\mathrm{C}_{12: 0}$ が $5.2 \mathrm{mmol} / \mathrm{gVSS}$ と一番 小く, $\mathrm{C}_{10: 0}, \mathrm{C}_{14: 0}, \mathrm{C}_{16: 0}, \mathrm{C}_{18: 0}$ の間では炭素数の増加に 伴って大きくなっている.これはLFAによるメタン 生成反応への阻害効果は炭素数の増加に伴い, 低く なることを意味している.さらに, $\mathrm{C}_{18}$ に関しては飽 和および不飽和の $\mathrm{L}_{\mathrm{i}}^{*}$ を比較すると，不飽和の $\mathrm{C}_{18}$ は 飽和の $\mathrm{C}_{18: 0}$ に比べてより大きい阻害効果を示した.

一方, 工学的見地からは, 活性がゼロになる阻害剤 負荷よりも微生物の代謝活性に顕著な阻害効果をも たらし始める阻害剤負荷の方がより重要な意味を持 つ.ここでは活性が $10 \%$ 低下した場合に反応槽の運 転に明らかな影響を与えると考え，阻害を防止する
Table 3 Comparison of $\mathrm{MIL}_{10}$ and $\mathrm{MIL}_{50}$ for various LFA at mesophilic and thermophilic condition.

\begin{tabular}{l|cc|cc}
\hline LFA & \multicolumn{2}{|c|}{$\mathrm{MIL}_{10}\left(\mathrm{mmol} / \mathrm{gVSS}^{\circ}\right.$} & \multicolumn{2}{|c}{$\mathrm{MIL}_{50}(\mathrm{mmol} / \mathrm{gVSS})$} \\
& $35^{\circ} \mathrm{C}$ & $55^{\circ} \mathrm{C}$ & $35^{\circ} \mathrm{C}$ & $55^{\circ} \mathrm{C}$ \\
\hline $\mathrm{C}_{10: 0}$ & 1.2 & 4.4 & 6.3 & 13 \\
$\mathrm{C}_{12: 0}$ & 1.0 & 0.50 & 3.9 & 2.6 \\
$\mathrm{C}_{14: 0}$ & 3.6 & 0.50 & 12 & 2.3 \\
$\mathrm{C}_{16: 0}$ & 3.7 & 4.7 & 12 & 21 \\
$\mathrm{C}_{18: 0}$ & 1.5 & 3.1 & 8.6 & 17 \\
$\mathrm{C}_{18: 1}$ (trans) & 1.4 & 2.3 & 8.0 & 13 \\
$\mathrm{C}_{18: 1}$ (cis) & 0.011 & 0.051 & 0.057 & 0.32 \\
$\mathrm{C}_{18: 2}$ & 0.0040 & 0.014 & 0.021 & 0.071 \\
$\mathrm{C}_{18: 3}$ & 0.043 & 0.079 & 0.10 & 0.12 \\
\hline
\end{tabular}

ための最大許容負荷として $\mathrm{MIL}_{10}$ を用いた. また，一 般に活性を $50 \%$ 低下させる阻害剂濃度は $\mathrm{MIC}_{50}$ 之呼 ばれており阻害研究で最もよく用いられる指標であ る9)-11)が, 本研究で用いたLFAによる阻害は菌体量と 重要な関係があるため活性を50\% 低下させる阻害剤 負荷である $\mathrm{MIL}_{50}$ を用いる方が適している. そこで Fig. 3に示すようにメタン生成活性に10\%および50\% の低下をもたらすLFAの負荷を $\mathrm{MIL}_{10}$ および $\mathrm{MIL}_{50}$ と 定義した. Table 3には中温および高温における各種 LFAの $\mathrm{MIL}_{10}$ および $\mathrm{MIL}_{50}$ を式(3)と Table 2 に示した パラメー夕を用いて算出した結果をまとめた. 同一 のLFAに対する高温での $\mathrm{MIL}_{10}$ および $\mathrm{MIL}_{50}$ は中温の それより高く, 中温条件での阻害効果が大きいこと を示唆している，同じ温度条件で比較すると，飽和 LFAの $\mathrm{MIL}_{10}$ と $\mathrm{MIL}_{50}$ は $\mathrm{C}_{12: 0}$ が最も小さく, 全体の傾 向として炭素数の増加に伴って大きくなった. 即ち, 炭素数が少ないほど阻害効果が強い傾向がある.な 
お，同じ $\mathrm{C}_{18}$ の飽和 LFA および不飽和 LFA の阻害効 果を比較すると, 中温における $\mathrm{MIL}_{10}$ と $\mathrm{MIL}_{50}$ の大き さはいずれも $\mathrm{C}_{18: 2}<\mathrm{C}_{18: 1}(\mathrm{cis})<\mathrm{C}_{18: 3}<\mathrm{C}_{18: 1}($ trans $)<$ $\mathrm{C}_{\text {18:0 }}$ であるのに対して, 高温における $\mathrm{MIL}_{10}$ の大きさ は $\mathrm{C}_{18: 2}<\mathrm{C}_{18: 1}$ (cis) $<\mathrm{C}_{18: 3}<\mathrm{C}_{18: 1}$ (trans) $<\mathrm{C}_{18: 0}$ であり, $\mathrm{MIL}_{50}$ の大きさは $\mathrm{C}_{18: 2}<\mathrm{C}_{18: 3}<\mathrm{C}_{18: 1}(\mathrm{cis})<\mathrm{C}_{18: 1}$ (trans) $<$ $\mathrm{C}_{18: 0}$ となった. 不飽和LFAは飽和LFAよりも強い阻 害効果を有しており, また不飽和LFAの中でも $\mathrm{C}_{18: 2}$, $\mathrm{C}_{18: 3}, \mathrm{C}_{18: 1}$ (cis)の阻害効果は大きかった.

\section{4. 考察}

\section{（1）LFAの分子構造と阻害性との関係}

LFA は細菌に吸着して阻害を起こすことから ${ }^{8), 21)}$, 阻害強さは菌体当りのLFA負荷量で表す方が適して いる．LFAによる細菌の代謝活性への阻害効果につ いては部分的ではあるが幾つかの報告がある ${ }^{9)-11)}$. Koster ら ${ }^{9)}$ は, UASB プロセスのグラニュールを用い て, $30^{\circ} \mathrm{C}$ で䣷酸資化性メタン生成に対するLFAの阻 害実験を行い, $\mathrm{C}_{10: 0}, \mathrm{C}_{12: 0}, \mathrm{C}_{14: 0}, \mathrm{C}_{18: 1}$ (cis)の $\mathrm{MIL}_{50}$ 値 はそれぞれ $0.98,0.72,0.80$ および $0.73 \mathrm{mmol} / \mathrm{gVSS} て ゙$

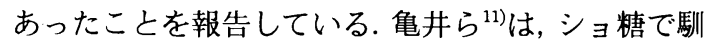
致したグラニュールを用い, $35^{\circ} \mathrm{C} て ゙$ 酷酸資化メタン生 成に対するLFAの阻害実験を行った結果, $\mathrm{C}_{10: 0}, \mathrm{C}_{12: 0}$, $\mathrm{C}_{14: 0}, \mathrm{C}_{16: 0}, \mathrm{C}_{18: 0}, \mathrm{C}_{18: 1}(\mathrm{cis})$ の $\mathrm{MIL}_{50}$ 值はそれぞれ 1.33 ,

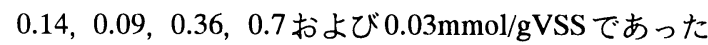
ことを報告した。 このように従来の研究は中温嫌気 性処理に集中している. 本研究では9種 LFAのそれ ぞれの阻害効果を系統的に検討した結果, 中温の $\mathrm{MIL}_{50}$ は $\mathrm{C}_{10: 0}: 6.3, \mathrm{C}_{12: 0}: 3.9, \mathrm{C}_{14: 0}: 12, \mathrm{C}_{16: 0}: 12$, $\mathrm{C}_{18: 0}: 8.6, \mathrm{C}_{18: 1}$ (trans) : 8.0, $\mathrm{C}_{18: 1}$ (cis): 0.057, $\mathrm{C}_{18: 2}$ : $0.021, \mathrm{C}_{18: 3}: 0.10 \mathrm{mmol} / \mathrm{gVSS}$ であって, 全体として

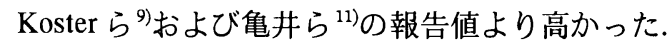

LFAによる細菌の代謝活性への阻害効果は LFAの 分子構造亡密切な関係がある. Koster ら ${ }^{9}$ の研究で は, 阻害効果強さの順は $\mathrm{C}_{12: 0}>\mathrm{C}_{18: 1}>\mathrm{C}_{14: 0}>\mathrm{C}_{10: 0}>$ $\mathrm{C}_{8: 0}$ であり, 飽和 LFA 中で $\mathrm{C}_{12: 0}$ による阻害が最も強 いとされている，亀井ら ${ }^{11}$ の研究では，阻害強さは $\mathrm{C}_{18: 1}>\mathrm{C}_{14: 0}>\mathrm{C}_{12: 0}>\mathrm{C}_{16: 0}>\mathrm{C}_{18: 0}>\mathrm{C}_{10: 0}>\mathrm{C}_{8: 0}$ であり, 飽 和LFAでは $C_{14: 0}$ による阻害が最も強いことが明らか にされている. Galbraith ら ${ }^{24)}$ は, 純粋培養した数種類 の細菌の活性に及ぼす飽和LFAおよび不飽和LFAの 阻害効果を比較した結果, 飽和LFAの阻害の強さは, $\mathrm{C}_{8: 0}<\mathrm{C}_{10: 0}<\mathrm{C}_{12: 0} \geq \mathrm{C}_{14: 0}>\mathrm{C}_{16: 0} \geq \mathrm{C}_{18: 0}$ であり, $\mathrm{C}_{12: 0}$ と $\mathrm{C}_{14: 0}$ による阻害効果が大きかったと報告している. ま た, 不飽和LFAについては, $\mathrm{C}_{18: 0}<\mathrm{C}_{18: 1}$ (trans) $<\mathrm{C}_{18: 1}$ (cis) $<\mathrm{C}_{18: 2} \leq \mathrm{C}_{18: 3}$ の順番になっており， $\mathrm{C}_{18: 2}$ と $\mathrm{C}_{18: 3}$ によ る阻害効果は特に大きかった. 本研究では飽和 LFA
の場合, 中温において $\mathrm{C}_{12: 0}>\mathrm{C}_{10: 0}>\mathrm{C}_{18: 0}>\mathrm{C}_{\text {14:0 }}=$ $\mathrm{C}_{\text {16:0 }}$ であるのに対して, 高温では $\mathrm{C}_{14: 0}>\mathrm{C}_{12: 0}>\mathrm{C}_{10: 0}$ $>\mathrm{C}_{18: 0}>\mathrm{C}_{16: 0}$ であった. また, $\mathrm{C}_{18}$ で比較すると, 中 温において, $\mathrm{C}_{18: 2}>\mathrm{C}_{18: 1}(\mathrm{cis}), \mathrm{C}_{18: 3}>\mathrm{C}_{18: 1}$ (trans) $>\mathrm{C}_{18: 0}$ であるのに対して, 高温では $\mathrm{C}_{18: 2}>\mathrm{C}_{18: 3}>\mathrm{C}_{18: 1}(\mathrm{cis})>$ $\mathrm{C}_{\text {18:1 }}$ (trans) > $\mathrm{C}_{18: 0}$ であった，つまり，飽和 LFAでは， $\mathrm{C}_{12: 0}, \mathrm{C}_{14: 0}$ による阻害効果が大きく, 不飽和LFAでは $\mathrm{C}_{18: 2}, \mathrm{C}_{18: 1}$ (cis)， $\mathrm{C}_{18: 3}$ による阻害効果が大きかった.

\section{（2）LFAの㻋水性と阻害性との関係}

LFAによる阻害効果はLFAの溶解性, 疎水性および 分子の表面面積亡関係することが指摘されており ${ }^{24)}$, LFAが阻害効果を表すためには水に溶解する必要が あることから, 水への溶解性が高いほど阻害効果は 大きくなり，LFAの疎水性が大きいほどLFA と細菌 の親和性が高まることから阻害効果は大きくなる. 飽和 LFA は炭素数の増加に従って溶解性が低下し, 疎水性が増大するため, 溶解性および柾水性による 総合的阻害効果は中温においては $\mathrm{C}_{12: 0}$ で最大となり, 結果として $\mathrm{C}_{12: 0}$ による阻害効果が一番高くなると考 えられており ${ }^{24)}$, 本研究の場合も中温では $\mathrm{C}_{12: 0}$ によ る阻害効果が最も高い傾向を示した. $\mathrm{C}_{18}$ 不飽和 LFA の場合 $\left(\mathrm{C}_{18: 1}\right.$ (trans )例外) 飽和 LFA と違い, 水和物之 して水に溶解することから, 水への溶解性と高い疎 水性を併せ持つため阻害性が強くなる24). また, 5 種 類のC ${ }_{18}$ による阻害効果が異なることは溶解性とその 界面特性の違いが原因と考えられる. 不飽和 LFA は 飽和LFAより分子の表面面積が大きく, cis型は trans 型より表面面積が大きいこと年が明らかになってお り，LFAの表面面積が大きいほど阻害性は強くなる ことから, 本研究で阻害性の強さが $\mathrm{C}_{18: 1}$ (trans) $>\mathrm{C}_{18: 0}$ と なった原因は LFAの表面面積の増大であり, $\mathrm{C}_{18: 1}$ (cis) $>\mathrm{C}_{18: 1}$ (trans)の原因は溶解性亡表面面積が増加するため であると考えられる. また, 二重鎖数が増加するほど 阻害性は高くなる ${ }^{24)}$ 傾向と $\mathrm{C}_{18: 2}$ と $\mathrm{C}_{18: 3}$ の阻害性が高 くなったことは一致した.

\section{（3）温度と阻害性との関係}

Nemethy-Scherage ${ }^{25)}$ によると, 非極性有機分子が水 中に存在する時, van der Waals-London 分散力および 水状構造の生成によってエンタルピーは変化する. エンタルピーは踈水性相互作用の安定性に影響を及 ぼす重要な因子であることが指摘されており, エン夕 ルピーが大きいほど疎水性相互作用は安定である ${ }^{26)}$. 例えば Leucine-isoleucine 間の疎水性相互作用は, $70^{\circ} \mathrm{C}$ 以下では, 温度の上昇につれて, エンタルピー が減少するため弱くなること, また, その他の結合の 温度依存性も Leucine-isoleucine の結合亡類似してい 
ることが報告されている ${ }^{25)}$. 本研究において中温に 比較して高温における阻害効果が低くなったことは, 高温におけるLFA と菌体の疎水性相互作用が中温に 比較して弱くなったことが原因である可能性がある.

\section{5. 結論}

中温および高温における酢酸資化性メタン生成活 性に対する各種LFAの阻害特性について比較検討を 行った結果, 以下の結論が得られた.

(1) $\mathrm{C}_{10: 0}, \mathrm{C}_{12: 0,}, \mathrm{C}_{14: 0}, \mathrm{C}_{16: 0}, \mathrm{C}_{18: 0}, \mathrm{C}_{18: 1}$ (trans), $\mathrm{C}_{18: 1}$ (cis), $\mathrm{C}_{18: 2}, \mathrm{C}_{18: 3}$ の各種LFAによる阻害効果は中温と比 較して, 高温で小さかった. 即ち, 多くのLFAに よる阻害は高温で緩和された。

(2) 実験した 9 種類の LFAの中で中温および高温のい ずれの条件においても不飽和LFAである $\mathrm{C}_{18: 2}, \mathrm{C}_{18: 3}$, $\mathrm{C}_{18: 1}$ (cis)による阻害効果は大きく, 次に $\mathrm{C}_{12: 0}, \mathrm{C}_{14: 0}$, $\mathrm{C}_{\text {10:0 }}$ であり, $\mathrm{C}_{16: 0}, \mathrm{C}_{18: 0}$ および $\mathrm{C}_{18: 1}$ (trans)による阻 害効果は比較的小さかった.

(3) $\mathrm{MIL}_{50}$ から判断した阻害の強さは, 飽和 LFA で比 較すると，中温では $\mathrm{C}_{12: 0}>\mathrm{C}_{10: 0}>\mathrm{C}_{18: 0}>\mathrm{C}_{14: 0}=\mathrm{C}_{16: 0}$ であるのに対して, 高温では $\mathrm{C}_{14: 0}>\mathrm{C}_{12: 0}>\mathrm{C}_{10: 0}>$ $\mathrm{C}_{18: 0}>\mathrm{C}_{16: 0}$ であった. また, $\mathrm{C}_{18}$ で比較すると, 中 温では, $\mathrm{C}_{18: 2}>\mathrm{C}_{18: 1}$ (cis), $\mathrm{C}_{18: 3}>\mathrm{C}_{18: 1}$ (trans) $>\mathrm{C}_{18: 0}$ であるのに対して, 高温では $\mathrm{C}_{18: 2}>\mathrm{C}_{18: 3}>\mathrm{C}_{18: 1}(\mathrm{cis})$ $>\mathrm{C}_{18: 1}($ trans $)>\mathrm{C}_{18: 0}$ となった.

\section{参考文献}

1）沈振訔, 周暁倹, 李玉友, 野池達也: アミノ酸系排水の 嫌気性ろ床および嫌気性ハイプリットリアクターにおけ る性能比較, 水環境学会誌, Vol.17, No. 2, pp. 99-108, 1994.

2) You, H.S. : Examples of the assessment in the food processing wastewater treament process, The workshop of the assesssment technology of wastewater treatment process and the technology of anaerobic fluidized bed in wastewater treatment, Shinjwu , Taiwan, pp. 4-21, 1991.

3) Quemeneur, M. and Marty, Y. : Fatty acids and sterols in domestic wastewaters, Wat. Res., Vol. 28, No. 5, pp. 12171226, 1994.

4) Eastman, J.A. and Ferguson, J.F. : Solubilization of particulate organic carbon during the acid phase of anaerobic digestion, J. WPCF, Vol.53, No. 3, pp. 352-366, 1981.

5) Ma, A.N. and Ong, A.S.H. : Palm oil processing - new development in effluent treatment, Wat. Sci. Technol., Vol.18, pp, 35-40, 1986.

6) Hanaki, K., Matsuo, T. and Kumazaki, K. : Treatment of oily cafeteria wastewater by single-phase and two-phasse anaerobic filter, Wat. Sci. Technol., Vol. 22, pp. 299-306, 1990.

7) 山口隆司, 原田秀樹, 桃井清至, 曽怡禎 : 高級脂肪酸の
嫌気的分解過程における硫酸塩還元菌の生態学的役割, 水環境学会誌,Vol. 6, No. 18, pp. 499-510, 1995.

8) 花木啓祐, 松尾友矩, 長瀬道彦: 嫌気性消化における脂 肪酸の代謝, 下水道協会誌, 18, 30-39, 1981 .

9) Koster, I.W. and Cramer, A. : Inhibition of methanogenesis from acetate in granular sludge by long-chain fatty acids, Appl. Environ. Microbiol., Vol. 53, pp. 403-409, 1987.

10) Prins, R.A., Van Nevel, C.J. and Demeyer, D.I. : Pure culture studies of inhibitors for methanogenic bacteria, Antonie van Leeuwenhoek, Vol. 38, pp. 281-287, 1972.

11) 龟井昌敏, 桃井清至, 原田秀樹, 滝沢智, 津恵直美: 上昇 流嫌気性スラジッベッド反応槽による脂質含有廃水の嫌 気性処理，水処理技術，Vol. 30, pp. 17-25, 1989.

12) Komatsu, T., Hanaki, K. and Matsuo, T. : Prevention of lipid inhibition in anaerobic processes by introducing a two-phase system, Wat. Sci. Technol., Vol. 23, pp. 1189-1200, 1989.

13) Aki, I.A. and Ahring, B.K. : Establishment and characterization of an anaerobic thermophilic $\left(55^{\circ} \mathrm{C}\right)$ enrichment culture degrading long-chain fatty acids, Appl. Environ. Microbiol., Vol.7, pp. 2442-2445, 1995.

14) Ahring, B.K. : Status on science and application of thermophilic anaerobic digestion, Proc. 7th Int. Symp. on Anaerobic Digestion, South Africa, pp. 328-337, 1994.

15) Wiegant, W. M., Claassen, J.A. and Lettinga, G. : Thermophilic anaerobic digestion of high strength wasterwaters, Biotechnol. Bioeng., Vol. 27, pp.1374-1381, 1985.

16) Souza, M.E., Fuzaro, G. and Polegato, A.R. : Thermophilic anaerobic digestion of vinasse in pilot plant UASB reactor, Wat. Sci. Technol., Vol. 25, No.7, pp. 213-222, 1992.

17) McDougall, F.R., Anderson, G.K. and Evison, L.M. : Twophase anaerobic digestion of coffee wastewater, Proc. 48th Industrial Waste Conf. May 10 12, 1993, Purdue University, pp. 677-683, 1993.

18) Harris, W.L., Wirtz, R.A., Sung, S. and Dague, R.R. : Anaerobic filter treatment of furfural byproduct wastewater Proc. 46th Industrial Waste Conf. May 14 16, Purdue University, pp. 689-695, 1991

19) Eroglu, V., Ozturk, I. and Bircan, E. : Upgrading the anaerobic contact process capacity using polyurethane carriers, Proc.45th Industrial Waste Conf. May 8 10, Purdue University, pp. 417-423, 1990.

20) Gang, L.B. and Mori, T. : Complete treatment of shochu processed wastewater by thermophilic oxic process, Proc. Environ. Eng. Res., Vol. 30, pp. 165-174, 1993.

21) 小松俊哉, 花木啓祐,松尾友矩 : 嫌気性消化における不飽 和高級脂肪酸阻害及び分解過程, 衛生工学研究論文集, Vol. 26, pp. 1-8, 1990.

22) 古米弘明, 松本明人, 松本順一郎 : 嫌気性膨張床におけ るメタン生成に及ぼす流入負荷の影響, 下水道協会誌, Vol. 24, No. 280, pp. 25-34, 1987.

23) Han, K. and Levenspiel, O. : Extended monod kinetics for substrate, product, and cell inhibition, Biotechnol. Bioeng., Vol. 32, pp. 430-437, 1988. 
24) Galbraith, H., Miller, T.B., Paton, A.M. and Thompson, J.K. : Antibacterial activity of long chain fatty acids and the reversal with calcium, magnesium, ergocalciferol and cholesterol, $J$. Appl. Bact., Vol. 34, No. 4, pp. 803-813, 1971.

25) Nemethy, G. and Scheraga, H.A. : The structure of water and hydrophobic bonding in proteins. III. The thermodynamic properties of hydrophobic bonds in proteins, J. Phys. Chem. Vol. 66, pp. 1773-1789, 1962.

26)伊勢典夫：静電的および疎水性相互作用と機能, 化学棇 説, Vol. 17, pp. 69-90, 1977.

\title{
A COMPARATIVE STUDY ON THE INHIBITARY EFFECT OF LONG-CHAIN FATTY ACIDS TO MESOPHILIC AND THERMOPHILIC METHANE FERMENTATION
}

\author{
Chun-Feng CHU, Yu-You LI, Takashi MIYAHARA and Tatsuya NOIKE
}

The inhibitory effects of long-chain fatty acids (LFAs) on methane fermentation from acetate under mesophilic $\left(35^{\circ} \mathrm{C}\right)$ and thermophilic $\left(55^{\circ} \mathrm{C}\right)$ conditions were investigated using batch anaerobic toxicity assays, Nine LFAs, including capric $\mathrm{C}_{10: 0^{\circ}}$ lauric $\mathrm{C}_{12: 0}$, myristic $\mathrm{C}_{14: 0}$, palmitoleic $\mathrm{C}_{16: 0}$, stearic $\mathrm{C}_{18: 0}$, oleic $\mathrm{C}_{18: 1}$ (cis), elaidic $\mathrm{C}_{18: 1}$ (trans), linoleic $\mathrm{C}_{18: 2}$, linolenic $\mathrm{C}_{18: 3}$ were used as the inhibitors. The inhibitory effect caused by LFAs under the thermophilic conditions were less than that under the mesophlic conditions and the unsaturated LFAs had higher inhibitory effect than saturated LFAs at the same temperatures. It was found that the inhibition caused by LFAs were correlated with the chemical structure and hydrophobicity of LFAs. 